\title{
Variation of male-biased maternal investment in fallow deer (Dama dama)
}

\author{
F. Braza*, C. San Josẻ and S. Aragỏn \\ Estaciỏn Biológica de Donana, Consejo Superior de Investigaciones Cientificas, Avenida de $M^{a}$ Luisa s/n, Pabellỏn del Perủ, 41013 Sevilla, Spain
}

(Accepted 28 April 1999)

\begin{abstract}
In this study 529 fallow deer fawns were captured and weighed at Donana National Park, Spain. An annual index of male-biased maternal investment (MBMI) was calculated, and this index was found to vary in relation to environmental factors. Thus, the level of MBMI was sensitive to fluctuations of autumn rainfall and the male-biased maternal investment carried out by mothers in the previous year $\left(\mathrm{MBMI}_{\mathrm{P}}\right)$. Our results reveal that those factors related to the female's body condition at the beginning of gestation have a high contribution to the variation of differential pre-natal maternal investment. It has been hypothesized by other authors that male-biased maternal investment is limited by the level of total maternal expenditure and these authors classified the fallow deer as a species near to its maximum reproductive effort, in which no sex-biased maternal investment exists. Our study reveals that male-biased maternal investment in fallow deer does exist and supports the hypothesis that sensitivity of maternal investment to environmental conditions could be expected to occur in species with high reproductive effort and sex-biased maternal investment.
\end{abstract}

Key words: Dama dama, fallow deer, male-biased maternal investment

\section{INTRODUCTION}

In polygynous mammals, where variance in reproductive success is greater in males than in females and is influenced by the amount of parental investment they receive, the investment theory predicts that parental investment will be sex-biased towards males (Trivers \& Willard, 1973; Maynard Smith, 1980).

Among polygynous ungulates, differential parental investment occurs in certain species (i.e. Clutton-Brock, Guinness \& Albon, 1982; Lee \& Moss, 1986; Hogg, Hass \& Jemi, 1992; Kojola, 1993). Two studies have discussed the hypothesis that sex-biased maternal investment could be limited by total maternal expenditure in polygynous ungulates: while Byers \& Moodie (1990) concluded that the differential investment across species was negatively related to the level of total maternal expenditure, Pèlabon et al. (1995) did not find any relationship between sex-biased care and total maternal expenditure across different species.

The main problem in studies on parental investment is how to measure maternal expenditure. Byers \& Moodie (1990) based their hypothesis on the fact that a greater

*All correspondence to: Francisco Braza.

E-mail: braza@ebd03.ebd.csic.es part of the total cost of reproduction in ungulates occurs during lactation (see also Oftedal, 1984; Gittleman \& Thompson, 1988). Pèlabon et al. (1995) showed a list of studies (see Fletcher, 1971; Anderson \& Fedak, 1987; Festa-Bianchet, 1988; Lee, Majluf \& Gordon, 1991; Birgersson \& Ekvall, 1997), which allowed them to consider birth weight as a more suitable variable than either post-natal growth or suckling performance to represent maternal expenditure. Birgersson \& Ekvall (1997) suggested that the greater weight and size of male fallow deer Dama dama at birth and their faster growth compared with female offspring could determine their greater efficiency in suckling despite an equal frequency and duration of suckling. In fact, in the Donana fallow deer population some indications suggest that the physical condition of male fawns influences the mothers' behaviour, inducing a higher investment in heavier fawns (Braza \& San José, 1988). Thus, it seems that pre-natal investment in birth weight could determine the demand of post-natal investment.

Taking into account the positive correlation between birth weight and adult weight and reproductive success (Clutton-Brock, Albon \& Guinness, 1988; CluttonBrock, 1991), we consider birth weight an appropriate variable for measuring sex-biased maternal care in fallow deer. 
Previous studies on pre-natal investment in fallow deer revealed a bias towards males at birth: male fawns are born heavier and larger than females, and pre-natal growth is faster for males (Braza, San Josè \& Blom, 1988; Birgersson \& Ekvall, 1997).

Another aspect of parental investment is the variation in the level of maternal investment as a result of environmental fluctuations. At Donana, a Mediterranean area in south-western Spain, environmental conditions are unpredictable. The main mortality factors are predation and sporadic events, such as drought. In this area, environmental stress seems to play a more important role in the variation of fallow deer mating strategies than social stress (San Josè \& Braza, 1997). Furthermore, some results concerning the fallow deer fawning season at Donana revealed that population density and environmental conditions during the last month of gestation had repercussions on the reproductive performance of females (Braza, San Josẻ, Blom, Cases et al., 1990).

A hypothesis of energy constraint on sex-biased maternal expenditure related to environmental variations was recently proposed by Byers \& Hogg (1995): species far from the maximum reproductive effort should show a reproductive performance less sensitive to environmental variations than species near to the maximum possible level of maternal investment. According to this hypothesis (see also Byers \& Moodie, 1990), species near to the maximum reproductive effort should not have a bias in favour of male offspring.

Our aim was to test whether the yearly variation of the male-biased maternal investment is influenced by environmental variations and/or by the mother's previous maternal investment. Extra investment in male fawns after favourable weather conditions and low previous maternal investment could be expected.

\section{METHODS}

Donana National Park (south-western Spain) includes 3 main biotopes: sand dunes, Mediterranean shrubland, and marshes (Allier, Gonzảlez-Bernáldez \& Ramirez, 1974). The mean temperature ranges from $8-11^{\circ} \mathrm{C}$ in winter to $23-28^{\circ} \mathrm{C}$ in summer; rainfall fluctuates over the years and mainly occurs in autumn-winter $(x=415 \mathrm{~mm}, \mathrm{sD}=202)$ (data from 1980-96).

In Donana, $80 \%$ of the fallow population concentrates in an ecotone area between marshes and shrub (Braza, 1975; Ojeda et al., 1983; Braza \& Alvarez, 1987). This ecotone area of the Biological Reserve $(1 \times 6.5 \mathrm{~km}$, included in the National Park) was selected as the study area. The fallow deer population living in that area ranged from 103 to 373 individuals between 1981 and 1996 (summer census data; see Braza, San Josẻ, Blom, Cases et al., 1990 for method).

In Donana, the rutting season occurs during the first half of October (Braza, Garcia \& Alvarez, 1986). Females give birth to a single fawn at the end of May to the beginning of June (Braza, San Josè \& Blom, 1988;

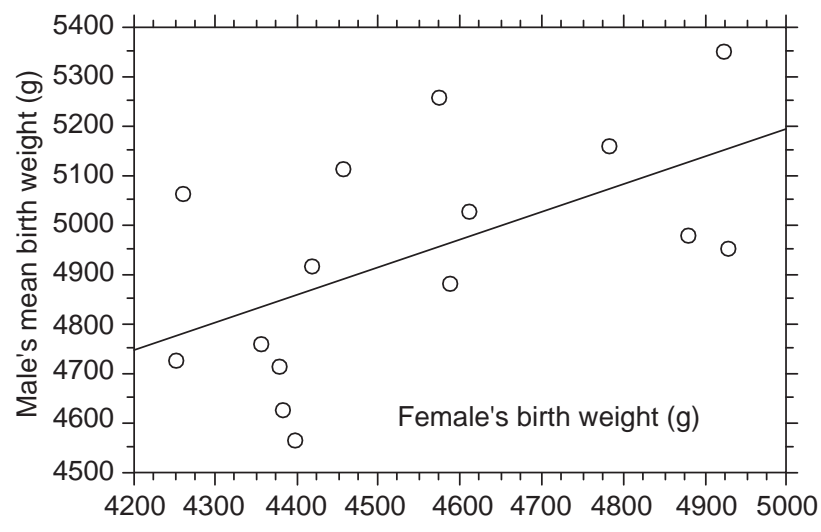

Fig. 1. Mean male weight at birth regressed on mean female weight at birth (means from 15 years: 1981-83 and 1985-96); $y=2447.044+0.548 * x ; R^{2}=0.319$

San Josẻ \& Braza, 1992). They mostly select the cover of rushes Juncus in the ecotone area for parturition (San Josẻ \& Braza, 1992).

Study sample and method

For 16 years (1981-96) the ecotone area of the Biological Reserve was searched daily during the fawning season to find newborn fawns. This was done on foot and sometimes with the assistance of a guard on horseback. A total of 529 fawns were marked with ear-tags and weighed, and their sex and age were recorded.

When birth was not seen the fawn's age was estimated according to the following criteria: the presence of remains of placenta, the still moist fur, the degree of healing of the umbilical cord, the hardening of the hooves and the presence of cartilage on their points (Braza, San Josẻ \& Blom, 1988; San Josẻ \& Braza, 1992; Pẻlabon, 1995).

Only data from 'newborn' fawns $(<24 \mathrm{~h})$ were used for the analysis; 1984 was excluded from this study because of the small sample size.

Variables considered and statistical analysis

Dependent variable

Male-biased maternal investment (MBMI)

We regressed the mean birth weight of male fawns on the mean birth weight of female fawns for each year, and used the residuals from this regression as an index of the extra-investment by mothers in male fawns (Fig. $1 ; \mathrm{R}^{2}=0.319, \mathrm{~F}=6.100, \mathrm{P}=0.0281$ ). This index was used as a dependent variable in a stepwise regression $(F$ to remove $=4$; StatView 4.5, Abacus Concepts, Inc. 1992-95) to analyse the factors contributing to the yearly variation in sex-biased maternal investment. 
Table 1. Principal component loadings from autumn-winter climatic variables in the study area over the period 1980-1996 ( $T=$ mean temperature, $R=$ accumulated rainfall, $T R=$ mean emperature and accumulated rainfall)

\begin{tabular}{lcc} 
& \multicolumn{2}{c}{ Principal components } \\
\cline { 2 - 3 } & \multicolumn{1}{c}{ I } & \multicolumn{1}{c}{ II } \\
& (TR Winter) & (Earliness R Autumn) \\
\hline T October-November & 0.749 & -0.302 \\
T December-January & 0.931 & -0.033 \\
T February-March & 0.184 & 0.043 \\
R October & -0.0003 & 0.777 \\
R November & -0.002 & -0.769 \\
R December & 0.841 & 0.349 \\
R January & 0.800 & -0.023 \\
R February & -0.168 & -0.0002 \\
R March & 0.312 & -0.014 \\
Eigen values & 3.10 & 1.71 \\
Proportion of variance & 34.50 & 19.00 \\
\hline
\end{tabular}

Independent variables

Male-biased maternal investment in the previous year $\left(\mathrm{MBMI}_{\mathrm{P}}\right)$

Calculated as MBMI on fawns born in the previous spring.

Climate in autumn-winter

Since data concerning forage productivity were not available, we used the climatic variables as an indirect measure of availability of resources in this season: monthly mean temperature and monthly accumulated rainfall for October-March for 1980-96. These variables were compacted by a principal components analysis (VARIMAX rotation; StatView 4.5, Abacus Concepts Inc. 1992-95). As Table 1 shows, the climatic principal components resulting from that analysis were temperature in autumn-winter, rainfall in winter (TR Winter) and rainfall in autumn (Earliness $R$ Autumn). These factors were included as independent variables in the stepwise regression.

Forage productivity

Measured in spring-summer as dry biomass per area $\left(\mathrm{kg} / \mathrm{m}^{2)}\right.$ (R. Soriguer, pers. comm.). Data of productivity were available for $1983-90$ and 1992-96 (range $=10-39$ $\mathrm{kg} / \mathrm{m}^{2}$ ).

Female density

Number of females per 100 ha in the study area; 7-32 female/100 ha (summer census data; see Braza, San Josè, Blom, Cases et al., 1990 for method).

Statistical analyses were performed according to Zar (1984). All tests were 2-tailed.

\section{RESULTS}

The mean fawn weight at birth was positively correlated with MBMI (Pearson's correlation, $r=0.530, P=0.040$; $n=15)$. No significant correlations were detected between sex-ratio at birth and mean fawn's birth weight ( $r=-0.253, P=0.3711$ ) or MBMI (Pearson's correlations: $r=0.140, P=0.6258)$.

We tested the effect of the $\mathrm{MBMI}_{\mathrm{P}}$, climatic factors in autumn-winter, forage productivity, and female density (independent variables) on the MBMI (dependent variable) in a stepwise regression. Table 2 reveals a negative contribution of both $\mathrm{MBMI}_{\mathrm{P}}$ and Earliness $\mathrm{R}$ Autumn to the MBMI. A lower $\mathrm{MBMI}_{\mathrm{P}}$, as well as a later autumn rainfall determined an increase in MBMI the following year. The independent variables were not significantly correlated (Pearson's correlations).

\section{DISCUSSION}

Our results revealed that male-biased maternal investment (MBMI) in fallow deer at Donana is affected by the earliness of autumn rainfall and the level of extramale investment made by mothers in the previous breeding season $\left(\mathrm{MBMI}_{\mathrm{P}}\right)$.

The yearly variation detected in MBMI establishes additional evidence that male-biased maternal investment in fallow deer is possible. Previous results related to adoptive behaviour in the same fallow deer population already suggested that a margin in the amount of parental investment allocated by a mother to her fawn probably exists, depending on different factors such as the sex of the fawn or its own physical condition (San Josẻ \& Braza, 1993).

Table 2. Male-biased maternal investment (MBMI) stepwise regression on climatic factors, forage productivity $\left(\mathrm{Kg} / \mathrm{m}^{2}\right)$, female density, and $\mathrm{MBMI}_{\mathrm{P}}$. Parameters after the second and last step

\begin{tabular}{|c|c|c|c|c|c|}
\hline $\begin{array}{l}\text { Multiple } R \\
\text { Multiple } \mathrm{R}^{2} \\
\text { Residuals } \\
\text { Analysis of variance }\end{array}$ & $\begin{array}{c}0.74 \\
0.54 \\
185.65 \\
\text { Sum of squares }\end{array}$ & $\begin{array}{l}\text { Adjusted } \mathrm{R}^{2} \\
\text { d.f. }\end{array}$ & $\begin{array}{l}0.44 \\
\text { Mean square }\end{array}$ & $\mathrm{F}$ & $\mathrm{P}$ \\
\hline $\begin{array}{l}\text { Regression } \\
\text { Residual }\end{array}$ & $\begin{array}{l}365887.98 \\
310193.70\end{array}$ & $\begin{array}{l}2 \\
9\end{array}$ & $\begin{array}{r}182943.99 \\
34465.97\end{array}$ & 5.308 & 0.03 \\
\hline Variables & Coefficient & $\mathrm{sE}$ & Standard coefficent & F-to-remove & \\
\hline $\begin{array}{l}\text { Intercept } \\
\text { Earliness R Autumn } \\
\text { MBMI }_{P}\end{array}$ & $\begin{array}{r}-22.82 \\
-143.58 \\
-0.48\end{array}$ & $\begin{array}{r}54.26 \\
50.76 \\
-0.24\end{array}$ & $\begin{array}{r}-22.82 \\
-0.65 \\
-0.47\end{array}$ & $\begin{array}{l}0.18 \\
7.99 \\
4.15\end{array}$ & \\
\hline
\end{tabular}


Furthermore, the fact that the level of MBMI was sensitive to environmental conditions and the $M B M I_{P}$, suggests that fallow deer can be considered as a high-reproductive-effort species. This agrees with Byers \& Hogg's (1995) hypothesis that predicts for ungulates a higher sensitivity of the reproductive performance to environ-mental conditions in high-reproductiveexpenditure species than in lower ones. However, we disagree with Byers \& Hogg's hypothesis (1995; see also Byers \& Moodie, 1990) when contending that females of high-reproductive-expenditure species do not show differential expenditure by offspring sex.

Our results show that sensitivity of maternal investment to environmental conditions could be expected to occur in species with high reproductive effort and sexbiased maternal investment, mainly in populations living under environmental stochasticity as in the fallow deer in Donana. Yearly fluctuations in the fawns' birth weight had already been detected in this population (Braza, San Josẻ \& Blom, 1988). The sensitivity of maternal investment to environmental conditions may be particularly evident in the extra-investment that mothers can afford to make in male offspring each year. In some species dimorphism in neonatal weight decreases (by lower male birth weights) when conditions become harsh (Skogland, 1990; Robertson et al., 1992), and variations in male-biased early growth affected by the mother's condition has been described for fallow deer (Birgersson \& Ekvall, 1997).

Concerning the detected influence of the females' previous reproductive effort $\left(\mathrm{MBMI}_{\mathrm{P}}\right)$ on the $\mathrm{MBMI}$ in the following breeding season, our results agree with the information proceeding from other studies on several species, which reveal a reduction in the subsequent reproductive performance of females after rearing male vs female offspring (Clutton-Brock, Guinness \& Albon, 1982; Lee \& Moss, 1986; Wolff, 1988; Clutton-Brock, Albon \& Guinness, 1989; Clutton-Brock, 1991; Bẻrubè, Festa-Bianchet \& Jorgenson, 1996; Clutton-Brock, Stevenson et al., 1996).

A negative influence of the earliness of autumn rainfall on the MBMI was also detected in the Donana fallow deer population, which could be related to two factors:

(1) Autumn forage productivity in Mediterranean habitats (Lazo, 1992) which could positively influence the mother's physical condition in winter. Although data on autumn forage productivity at Donana are not available, the most plausible hypothesis is that this variable affects the physical condition of mother and offspring in the early phase of gestation. A recent study on fallow deer (Birgersson \& Ekvall, 1997) has revealed that the fawn's birth mass and early growth rate were significantly correlated to the mother's body mass; furthermore, pre- and post-natal growth rates were higher for male fawns. Since sex-differences in growth rate seems to start at the beginning of gestation, the mother's physical condition at that moment could be influencing the initial growth rate of the offspring and the level of sex-differences in weight (through an extramale maternal investment) that will be maintained throughout the gestation.

According to several authors (see review in Gittleman \& Thompson, 1988) ungulates buffer the costs of gestation by laying down fat reserves before conception. In red deer the energy costs of gestation and lactation have a marked effect on the maternal condition during the summer and on subsequent fecundity (Clutton-Brock, Guinness \& Albon, 1982, 1983). Our study suggests that the physical condition of females at the moment of conception and early gestation also determines the level of extra-investment they can afford to make in male offspring.

(2) We would expect the most vigorous mothers to conceive and give birth earlier to larger offspring, as has been observed in other deer species (Clutton-Brock, Albon \& Guinness, 1984, 1986; Birgersson \& Ekvall, 1997). Our results reveal that the earliness of autumn rainfall seems to contribute negatively to the MBMI the following year. This could be a result of a delay in the rutting season caused by early autumn rainfall. This delay could decrease the number of bigger male offspring and the male fawn's birth weight the following year.

In summary, our study on fallow deer shows an effect of environmental factors and the mother's previous reproductive effort on the yearly variation of malebiased maternal investment, emphasizing the importance of the moment of conception and the early phase of gestation. Fallow deer can be considered as a species close to the maximum reproductive effort, but with a margin to vary the amount of maternal investment allocated to male fawns.

\section{Acknowledgements}

This paper has been supported by Dirección General de Investigación Cientifica y Tẻcnica (project PR84-0243C07-01 and PB87-0316), by Consejo Superior de Investigaciones Cientlficas and by the Junta de Andalucia. The study period was so long that many people (impossible to list) have been required and have been of great help, especially the guards at Donana, the different managers and staff in the Donana Biological Reserve. We thank Allard Blom, Annie and Rita Braza, Tica Cases, Juan E. Garcla Yuste, Alicia Prieto and Ivản Varela for their consistency and continuous assistance. Enrique Collado assisted us with the management and analysis of data for the results. Dr Fernando Alvarez not only participated in the fieldwork, but also critically revised the manuscript. We also thank Dr Pedro Jordano, Dr Javier Cuervo and Dr Sacramento Moreno for their assistance in the preparation of the manuscript, Dr Ramón Soriguer for providing unpublished data and the anonymous referees for helpful comments on the manuscript. 


\section{REFERENCES}

Allier, C., Gonzảlez-Bernảldez, F. \& Ramirez, L. (1974). Donana, mapa ecológico. Sevilla: Estación Biológica de Donana, CSIC.

Anderson, S. S. \& Fedak, M. A. (1987). Grey seal, Halichoerus grypas, energetics: females invest more in male offspring. J. Zool. (Lond). 211: 667-679.

Berubẻ, C. H., Festa-Bianchet, M. \& Jorgenson, J. T. (1996). Reproductive costs of sons and daughters in Rocky Mountain bighorn sheep. Behav. Ecol. 7:60-68.

Birgersson, B. \& Ekvall, K. (1997). Early growth in male and female fallow deer fawns. Behav. Ecol. 8: 493-499.

Braza, F. (1975). Censo del gamo (Dama dama) en Donana. Naturalia Hispanica 3: 1-27.

Braza, F. \& Alvarez, F. (1987). Habitat use by red deer and fallow deer in Donana National Park. Misc. Zool. 11: 363-367.

Braza, F., Garcla, J. E. \& Alvarez, F. (1986). Rutting behaviour of fallow deer. Acta Theriol. 31: 467-478.

Braza, F. \& San José, C. (1988). An analysis of mother-young behaviour of fallow deer during lactation period. Behav. Proc. 17: 93-106.

Braza, F., San Josè, C. \& Blom, A. (1988). Birth measurements, parturition dates, and progeny sex ratio of Dama dama in Donana, Spain. J. Mammal. 69: 607-610.

Braza, F., San Josè, C., Blom, A., Cases, V. \& Garcla, J. E. (1990). Population parameters of fallow deer at Donana National Park (SW Spain). Acta Theriol. 35: 277-288.

Byers, J. A. \& Hogg, J. T. (1995). Environmental effects on prenatal growth rate in pronghorn and bighorn: further evidence for energy constraint on sex-biased maternal expenditure. Behav. Ecol. 6: 451-457.

Byers, J. A. \& Moodie, J. D. (1990). Sex-specific maternal investment in pronghorn, and the question of a limit on differential provisioning in ungulates. Behav. Ecol. Sociobiol. 26:157-164.

Clutton-Brock, T. H. (1991). The evolution of parental care. Princeton, New Jersey: Princeton University Press.

Clutton-Brock, T. H., Albon, S. D. \& Guinness, F. E. (1984). Maternal dominance, breeding success and birth sex ratios in red deer. Nature 308: 358-360.

Clutton-Brock, T. H., Albon, S. D. \& Guinness, F. E. (1986). Great expectations: dominance, breeding success and offspring sex ratios in red deer. Anim. Behav. 34: 460—471.

Clutton-Brock, T. H., Albon, S. D. \& Guinness, F. E. (1988). Reproductive success in male and female red deer. In Reproductive success: 325-343. Clutton-Brock, T. H. (Ed.). Chicago: Chicago University Press.

Clutton-Brock, T. H., Albon, S. D. \& Guinness, F. E. (1989). Fitness costs of gestation and lactation in wild mammals. Nature 337: 260-262.

Clutton-Brock, T. H., Guinness, F.E. \& Albon, S. D. (1982). Red deer: behaviour and ecology of two sexes. Edinburgh: Edinburgh University Press.

Clutton-Brock, T. H., Guinness, F. E. \& Albon, S. D. (1983). The costs of reproduction to red deer hinds. J. Anim. Ecol. 52: 367-383.

Clutton-Brock, T. H., Stevenson, I. R., Marrow, P., MacColl, A. D., Houston, A. I. \& McNamara, J. M. (1996). Population fluctuations, reproductive costs and life-history tactics in female Soay sheep. J. Anim. Ecol. 65: 675-689.
Festa-Bianchet, M. (1988). Nursing behaviour of bighorn sheep, correlates of ewe age, parasitism, lamb age, birthdate and sex. Anim. Behav. 36: 1445-1454.

Fletcher, I. C. (1971). Relationships between frequency of suckling, lamb growth and post-partum oestrus behaviour in ewes. Anim. Behav. 19: 108-111.

Gittleman, J. L. \& Thompson, S. D. (1988). Energy allocation in mammalian reproduction. Am. Zool. 28: 863-875.

Hogg, J. T., Hass, C. C. \& Jemi, D. A. (1992). Sex-biased maternal investment expenditure in rocky mountain bighorn sheep. Behav. Ecol. Sociobiol. 31: 243-251.

Kojola, I. (1993). Early maternal investment and growth in reindeer. Can. J. Zool. 71: 753-758.

Lazo, A (1992). Socioecologia del ganado bovino asilvestrado de la Reserva Biológica de Donana. Ph D dissertation, Universidad de Sevilla.

Lee, P. C., Majluf, P. \& Gordon, I. J. (1991). Growth, weaning and maternal investment from a comparative perspective. J. Zool. (Lond). 225: 99-114.

Lee, P. C. \& Moss, C. J. (1986). Early maternal investment in male and female African elephant calves. Behav. Ecol. Sociobiol. 18: 353-361.

Maynard Smith, J. (1980). A new born theory of sexual investment. Behav. Ecol. Sociobiol. 7: 247-251.

Oftedal, O. T. (1984). Milk composition, milk yield and energy output at peak lactation: a comparative review. Symp. zool. Soc. Lond. No.51: 33-85.

Ojeda, G., Braza, F., Alvarez, F. \& Azcảrate, T. (1983). La población de gamos del Parque Nacional de Donana en 1979. Donana, Acta Vert. 10: 221-224.

Pèlabon, C. (1995). Variabilitẻ des critẻres d'estimation de l'age des faons de daim (Dama dama) au cours des premiers jours suivant la naissance. Mammalia 59: 141-146.

Pẻlabon, C., Gaillard, J. M., Loison, A. \& Portier, C. (1995). Is sex-biased maternal care limited by total maternal expenditure in polygynous ungulates? Behav. Ecol. Sociobiol. 37: 311-319.

Robertson, A., Hiraiwa-Hasegawa, M., Albon, S. D. \& CluttonBrock, T. H. (1992). Early growth and suckling behaviour of Soay sheep in fluctuating populations. J. Zool. (Lond). 227: 661-671.

San Josė, C. \& Braza, F. (1992). Antipredator aspects of fallow deer behaviour during calving season at Donana National Park (Spain). Ethol. Ecol. Evol. 4:139-149.

San Josẻ, C. \& Braza, F. (1993). Adoptive behaviour in fallow deer (Cervus dama). Z. Säugetirkd. 58: 122-123.

San Josè, C. \& Braza, F. (1997). Ecological and behavioural variables affecting the fallow deer mating system in Donana. Ethol. Ecol. Evol. 9: 133-148.

Skogland, T. (1990). Density dependence in a fluctuating wild rein-deer herd; maternal vs. offspring effects. Oecologia (Berl.) 84: $442-450$

Trivers, R. L. \& Willard, D. E. (1973). Natural selection of parental ability to vary the sex ratio of offspring. Science 179 : 90-92.

Wolff, J. O. (1988). Maternal investment and sex ratio adjustment in American bison. Behav. Ecol. Sociobiol. 23: 127-133.

Zar, J. H. (1984). Biostatistical analysis. New Jersey: PrenticeHall, Inc. 